in the country were also studied. The study and description of all new taxa were supervised by many orchid specialists. Twenty-seven new species and three new chorological records for the Colombian flora have been reported, represented as following for these genera: Acianthera Schweid. (2 new species), Campylocentrum Benth. (1 new species), Epidendrum L. (13 new species), Lepanthes Sw. (7 new species and two new records), Lockhartia Hook. (1 new species), Stelis Sw. (1 new species), and Telipogon Kunth (2 new species and one new record). Despite the high level of perturbation of these ecosystems and human pressures, orchid diversity and the amount of endemism are surprisingly high compared to those of similar, protected ecosystems from the same region. Nevertheless, the scarcity of populations of some of the new species demonstrates 1) the importance and utility of floristic inventories and protection of the orchid diversity of Colombian forests and páramos and 2) the need for urgent short- and long-term conservation strategies in order to save Colombian wild orchid populations from extinction.

\title{
Anotaciones sobre la composición de la comunidad de orquídeas en la Reserva Natural Bosque de Yotoco (Valle del Cauca, Colombia)
}

\section{Nhora Helena Ospina-Calderón ${ }^{1,2 *}$, Gina Arroyo-García ${ }^{2,3}$ \& J. Tupac Otero ${ }^{2,4,5}$}

'Facultad de Ciencias Naturales, Programa de Ecología, Fundación Universitaria de Popayán, Popayán, Colombia;

${ }^{2}$ Grupo de Investigación en Orquídeas, Ecología y Sistemática Vegetal. Universidad Nacional de Colombia Sede

Palmira. Palmira, Colombia; ${ }^{3}$ Departamento de Ciencias Biológicas, Programa de Ingeniería Agronómica, Universidad Nacional de Colombia Sede Palmira, Colombia; ${ }^{4} \mathrm{Facultad}$ de Ciencias Agropecuarias, Departamento de Ciencias Biológicas, Universidad Nacional de Colombia Sede Palmira, Colombia; ${ }^{5}$ Instituto de Estudios Ambientales IDEA, Palmira. Universidad Nacional de Colombia Sede Palmira, Colombia; *correspondencia: nhora_helena@yahoo.com

Durante el año 2009 se estudió, en La Reserva Natural Bosque de Yotoco, la flora orquideológica que caracteriza este bosque, uno de los últimos relictos boscosos del Valle del Cauca, Colombia. Con el fin de capturar la diversidad de esta familia de hierbas terrestres, rupícolas como epífitas; se trazaron de manera sistemática 104 transectos (69 verticales, 29 horizontales, 5 lineales) dentro del bosque, cubriendo más de $30000 \mathrm{~m} 2$. Se encontraron 91 morfoespecies, 81 determinadas hasta especie, Stelis spathulata y Stelis argentata las más abundantes, los forófitos más frecuentes Corbones (Poulseria armata), Caimitos (Paulteria caimito) y Lauraceas, sin embargo los más diversos fueron Eugenia sp. y Ficus insipida. Se registraron 19 nuevas especies, para un aproximado de 100 especies reportadas en la Reserva.

\section{Checklist and illustrated guide to the Cauca River Valley's orchids and the Andean foothills (southwestern Colombia)}

\section{G. A. Reina-Rodríguez ${ }^{*}$, N. H. OSpina-CALderón² ${ }^{2}$ Alejandro CASTaÑo ${ }^{3}$, IGNASI SORIANO 4 \& J. TUPAC OTERO ${ }^{5}$}

\begin{abstract}
${ }^{1,5^{*}}$ Plant Biology Department, Universidad de Barcelona, Spain; ${ }^{2}$ Ecology Program, Fundación Universitaria de Popayán, Colombia; ${ }^{3}$ Institute for Research and Preservation of Cultural and Natural Heritage of Valle del Cauca Department-INCIVA, Colombia; ${ }^{4}$ Plant Biology Department, Universidad de Barcelona, Spain; ${ }^{5}$ Environmental Studies Institute (IDEA Palmira), Universidad Nacional de Colombia, Palmira, Colombia

*Author for correspondence: guireina@hotmail.comena@yahoo.com
\end{abstract}

As part of the principal author's doctoral thesis, 21 dry forest patches were explored in the Cauca River Valley bioregion (421,000 ha) in southwestern Colombia.
Sampling was carried out from September 2009 to October 2010 at elevations between 930 and $1200 \mathrm{~m}$. Field work was carried out during 346 hours over a 
distance of $60 \mathrm{~km}$. This exploration produced the most complete list of orchids ever made in this territory, with a total of 70 species belonging to 41 genera. This list exceeds the previous record by 37 species $(112 \%)$ and represents $1.74 \%$ of the total of orchid species reported for Colombia. Several new regional records were found, as well as at least three endemic species and probably one local extinction. We detected five centers of high orchid concentration ("regional hot spots"), each with 2129 species. We found that total species richness of this bioregion (70 species in 421,000 hectares) is 842 times lower than the much smaller Yotoco forest adjacent to this area (69 species in 500 hectares). Possible explanations might be that plant diversity decreases when rainfall is low, and this is valid for orchids as well. However, other factors such as 130 years of habitat destruction (only $2 \%$ of dry forest remains) lead us to think that extinction has occurred. At the same time, an illustrated guide of these species was printed to increase public awareness of the importance of orchid conservation. Also, a digital high-resolution bank of images of the orchid flora of the department of Valle del Cauca was begun.

\title{
The orchid flora of Chorogo Wildlife Reserve, Puerto Armuelles, Chiriquí, Panamá
}

\author{
Zuleika Serracín-Hernández ${ }^{1 *}$, Rafael Rincón ${ }^{1}$, Eyvar Rodríguez-Quiel ${ }^{1}$ \\ \& Diego Bogarín ${ }^{1,2}$
}

${ }^{1}$ Herbario UCH, Universidad Autónoma de Chiriquí, P.O. Box 0427, Chiriquí, Panamá; 2Jardín Botánico Lankester, Universidad de Costa Rica, P.O. Box 302-7050, Cartago, Costa Rica; *correspondence: zuleika06887@hotmail.com

We performed a preliminary taxonomic study of the orchid flora of Chorogo Wildlife Reserve, Chiriqui, Panama. Chorogo is located $11 \mathrm{~km}$ west of Puerto Armuelles along the Panama-Costa Rica border and protects about 1,000 ha of lowland tropical wet forest with elevations of 344-572 m, average annual temperature of $27 \mathrm{C}$, and $226.5 \mathrm{~mm}$ of precipitation. Samples were collected at different sites of the reserve during three field trips. The material was cultivated and documented electronically by photographs and botanical plates with stereoscope, digital camera, and scanner. Specimens are kept in the reference collection of dried specimens, living plant collection, and spirit collection at the $\mathrm{UCH}$ herbarium. Identification was made by comparing the specimens with types and protologues. The information is available free online at the website Epidendra (www.epidendra.org). Composite plates, distribution, descriptions, ecology, etymology, synonymy, taxonomy, and photographs are provided for each of the 15 species belonging to 11 genera recorded. Of these, seven are new records for the province of Chiriquí. Epidendrum coronatum and Mormodes fractiflexa are considered vulnerable by national conservation criteria. Together with studies conducted in the Pacific of Costa Rica, this project aims to strengthen the understanding of the orchid flora protected by both countries on the Pacific lowlands. It also represents the beginning of the study of the orchids of the protected areas of Panama.

\section{What delimitation for Stelis should be used?}

\section{Rodolfo Solano $^{1 *}$ \& Gerardo Salazar ${ }^{2}$}

${ }^{1}$ Centro Interdisciplinario de Investigación para el Desarrollo Integral Regional unidad Oaxaca, Instituto Politécnico Nacional, Oaxaca, México; ${ }^{2}$ Instituto de Ecología, Universidad Nacional Autónoma de México, México D.F., México; *Author for correspondence: solanogo@yahoo.com.mx

The use of DNA sequences for the phylogenetic reconstruction of subtribe Pleurothallidinae has led to a new delimitation of Stelis, and the genus now includes several groups that are morphologically heterogeneous (Stelis s.1.). Some authors do not accept this broader delimitation and recognize Stelis in its narrow sense (Stelis s.s.), raising to generic level those related groups (Crocodeilanthae, Dracontia, 